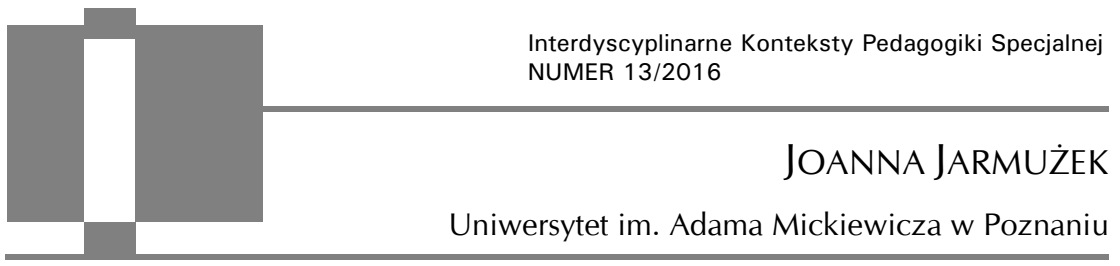

\title{
Wybrane aspekty aktywności edukacyjnej i zawodowej młodych osób z niepełnosprawnościami
}

\begin{abstract}
Joanna Jarmużek, Wybrane aspekty aktywności edukacyjnej i zawodowej młodych osób z niepetnosprawnościami [Selected aspects of educational and occupational activity of young people with disabilities]. Interdyscyplinarne Konteksty Pedagogiki Specjalnej, nr 13, Poznań 2016. Pp. 125-140. Adam Mickiewicz University Press. ISSN 2300-391X
\end{abstract}

The aim of the publication is to present selected aspects of starting adult life by the people with disabilities. Young adults, entering adult life, verify their plans and life goals, and tries to fulfill the life tasks typical of this stage in a satisfactory way. In certain special situations (such as disability), meeting these challenges can be difficult. The article will discuss selected aspects of the educational and occupational activity of young people with disabilities.

KEY WORDS: people with disabilities, vocational activity, professional counseling, education, quality of life, barriers, stereotypes

Dorosłość bywa różnie postrzegana - przez jednych jako oczywisty, naturalny etap rozwojowy następujący po adolescencji, w który wkraczamy $\mathrm{z}$ racji wieku; przez innych jako stadium życiowe, które wiąże się z wolnością i odpowiedzialnością, możliwością wpływu i wyboru na to, jak dorosłe życie będzie wyglądać. Już sam początek dorosłości jest szeroko definiowany: jako moment 
osiągnięcia pełnoletniości, jako etap następujący po burzliwym biologicznym i psychicznym dojrzewaniu ${ }^{1}$ albo z rozwojowego punktu widzenia jako stadium, gdy człowiek zaczyna żyć jak osoba dorosła realizująca swoje zobowiązania względem rodziny i społeczności². Wspomniane interpretacje wczesnej dorosłości wskazują na dwie wzajemnie uzupełniające się perspektywy analizy rozwoju człowieka: stadialną (realizację zdań rozwojowych, osiąganie kompetencji) i cyrkularną (powracanie do wcześniejszych projektów, działań, planów, pomysłów ich modyfikowanie i ponowna realizacja w nowej jakości) ${ }^{3}$. Życie młodego dorosłego będzie w bardzo dużym stopniu zależało od tego, czy pozytywnie rozwiązał kryzys tożsamości i czy w okresie wczesnej dorosłości z sukcesem będzie realizować siebie i stojące przed nim zadania rozwojowe, edukacyjne i zawodowe. Obecnie coraz częściej można zauważyć odroczenie części zadań rozwojowych okresu wczesnej dorosłości ze względu na wydłużającą się fazę niestabilnej sytuacji życiowej, zwłaszcza zawodowej. Młode osoby coraz później decydują się na podejmowanie zadań i ról wynikających z dorosłości, takich jak zawieranie związków małżeńskich, rodzicielstwo czy rozpoczęcie stałej pracy zawodowej. Granica wiekowa między okresem adolescencji a wczesną dorosłością nieustannie przesuwa się w kierunku trzydziestego roku życia ${ }^{4}$.

Młody dorosły, posiadający określone ograniczenia, wkraczając w samodzielne życie doświadcza szczególnie trudnej sytuacji. Jego niepełna sprawność będzie utrudniać lub uniemożliwiać realizację założonych celów, planów i aspiracji. Młody człowiek, poza ograniczeniami wynikającymi z samej niepełnosprawności, musi borykać się z problemami natury psychologicznej, egzystencjalnej oraz społecznej. Tym trudniejsza jest akceptacja siebie, wybór drogi życiowej, realizacja własnej drogi życiowej, proces materialnego, przestrzenne-

${ }^{1}$ B. Harwas-Napierała, Dorosłość jako spetnienie. Drogi i zagrożenia rozwoju człowieka w okresie dorostości, Libron, Kraków 2012, s. 13-16.

${ }^{2}$ H. Bee, Psychologia rozwoju człowieka, Zysk i Spółka, Poznań 2008, s. 366.

${ }^{3}$ A. Brzezińska, Psychologiczne portrety człowieka, GWP, Gdańsk 2015, s. 7-39.

4 A. Brzezińska, R. Kaczan, K. Piotrowski, M. Rękosiewicz, Odroczona dorostość: fakt czy artefakt?, „Nauka” 2011, 4, s. 67-107. 
go oraz psychicznego usamodzielniania się oraz podejmowania decyzji edukacyjnych, zawodowych i zarobkowych. Stanisław Kowalik definiuje zakres zjawiska niepełnosprawności poprzez dokonanie umownego podziału osób na dwie grupy, różnicując je względem posiadanej sprawności: osoby $\mathrm{w}$ pełni sprawne $\mathrm{i}$ osoby $\mathrm{z}$ niepełną sprawnością. Czym jest więc posiadanie pełnej sprawności? Pełna sprawność oznaczać może tu dwie perspektywy postrzegania osoby. Pierwszy z nich dotyczy sprawności na poziomie jednostkowym we wszystkich obszarach życia, tj. na poziomie biologicznym, psychologicznym i społecznym osoby. Natomiast druga perspektywa dotyczy możliwości realizacji funkcji, zadań i celów wyznaczanych na poszczególnych etapach życia człowieka. Gdy nałożymy na siebie obie perspektywy, to możemy uzyskać kompletny obraz pełnosprawności: we wszystkich obszarach oraz na wszystkich etapach życia ${ }^{5}$.

Wkraczając we wczesną dorosłość, człowiek po raz pierwszy w życiu jest w pełni odpowiedzialny za każdą swoją decyzję i to tylko od niego będzie zależało, jaką drogę obierzét. Spójność wyborów życiowych z własną koncepcją siebie jest bardzo istotne, lecz wielokrotnie trudne w realizacji, szczególnie wtedy, gdy ktoś musi borykać się z różnorodnymi ograniczeniami. Ograniczenia te mogą mieć charakter zarówno barier wewnętrznych, jak i tych środowiskowych, mogą wynikać zarówno z ograniczeń mentalnych, społecznych, jak i biologicznych. Dlatego też młode osoby z niepełnosprawnościami tym bardziej muszą wykazać się determinacją i dojrzałością w poszukiwaniu i realizacji własnej drogi życia, zgodnej ze sformułowaną $\mathrm{w}$ okresie adolescencji tożsamością7. W artykule analizowane będą wybrane kwestie dotyczące aktywności edukacyjnej i zawodowej młodych osób wkraczających w dorosłość

${ }^{5}$ S. Kowalik, Psychologia rehabilitacji, Wydawnictwa Akademickie i Profesjonalne, Warszawa 2007.

${ }^{6}$ J. Jarmużek, Rozwojowe implikacje dorosłości, [w:] Edukacja. Uniwersytet. Oświata dorostych, red. W. Ambrozik, Wydawnictwo Naukowe UAM, Poznań 2014, s. 291-300.

7 A.I. Brzezińska, K. Piotrowski, Aktywność zawodowa osób z ograniczeniem sprawności - wyznaczniki społeczno-demograficzne i osobowościowe, Wydawnictwo SWPS „Academica”, Warszawa 2008. 


\section{Rola edukacji w życiu osób z niepełnosprawnościami}

Edukacja jest niewątpliwie jedną z najważniejszych inwestycji nie tylko społecznych, ale również gospodarczych i politycznych. Wykształcenie wyższe, rozumiane jako wprowadzenie do bardzo wyspecjalizowanej wiedzy, a zatem także do wyspecjalizowanego kręgu kulturowego, jest istotnym czynnikiem rozwoju człowieka, drogą awansu społeczno-zawodowego, istotnym dobrem. Poza tym pozyskanie wykształcenia stwarza młodej osobie możliwość bardziej satysfakcjonującego uczestnictwa w życiu społecznym. Poziom wykształcenia jako wskaźnik posiadanych zasobów kapitału społecznego osoby stanowi z jednej strony niezwykle istotny czynnik np. dla jej aktywności zawodowej, z drugiej strony istotnie zmniejsza zagrożenie wykluczeniem społecznym, wpływając tym samym na wyższy poziom jakości życia ${ }^{8}$. Dane jednoznacznie wskazują, że istnieje bezpośrednie powiązanie poziomu wykształcenia z aktywnością zawodową; im wyższy poziom wykształcenia osób niepełnosprawnych, tym wyższy współczynnik ich aktywności zawodowej oraz wskaźnik zatrudnienia9. Amadeusz Krause, podkreślając wartość wykształcenia, mówi o skonfrontowaniu osób niepełnosprawnych z tzw. efektem windy edukacyjnej, gdzie poszukiwanie pracy i jej selektywny charakter (wzrost zapotrzebowania na pracowników specjalizujących się w nowych technologiach, dobrze wykształconych) podwyższa poziom wykształcenia niezbędnego do aktywności zawodowej. Następuje również deprecjacja kompetencji, która polega na tym, że coraz wyższemu poziomowi wykształcenia towarzyszy coraz mniejsza liczba przywilejów i możliwości zatrudnienia. Można więc uznać, że jednostka o niskim poziomie wykształcenia pozbawia się praktycznie szans

8 Raport Edukacja w zarysie, OECD 2015, http://www.oecd-ilibrary.org/educa tion/education-at-a-glance-2015_eag-2015-en [dostęp: 27.05.2016]

${ }^{9}$ I. Raszeja-Ossowska, Młodzi - niepetnosprawni Sytuacja społeczna $i$ zawodowa, Fundacja Aktywizacja, Warszawa 2013, oraz Badania Aktywności Ekonomicznej Ludności (BAEL) oraz GUS 2016, http://stat.gov.pl/informacja-o-badaniach-ankietowych/ba danie-aktywnosci-ekonomicznej-ludnosci-bael/ [dostęp: 24.05.2016] 
w wyścigu do podziału korzyści ${ }^{10}$. Trzeba w tym miejscu wskazać, iż o ile dla osób sprawnych efekt windy oznacza jedynie zmniejszenie szans, o tyle dla osób niepełnosprawnych ich całkowitą redukcję. W dzisiejszej sytuacji na wolnym rynku pracy jest on prawie niedostępny dla osób z niepełnosprawnościami ${ }^{11}$.

Pozytywnym zjawiskiem $w$ ostatnich latach jest systematyczny wzrost poziomu wykształcenia osób niepełnosprawnych ${ }^{12}$. Trudna sytuacja na rynku pracy spowodowała, że coraz więcej młodych osób z niepełnosprawnościami, nie widząc dla siebie innych możliwości zaistnienia na rynku pracy, decyduje się na podjęcie nauki na studiach wyższych, stanowiących obecnie podstawę w budowaniu kariery zawodowej. Jak wykazują kolejne raporty GUS dotyczące edukacji w Polsce liczba studentów niepełnosprawnych stale rośnie ${ }^{13}$. Jednak nadal powyższa dynamika nie jest satysfakcjonująca dla integracji osób niepełnosprawnych ze społeczeństwem oraz $\mathrm{z}$ perspektywy aktywności $\mathrm{w}$ gospodarce opartej na wiedzy ${ }^{14}$. Po pierwsze odsetek osób niepełnosprawnych z wyższym wykształceniem rośnie o wiele wolniej niż wśród sprawnej części społeczeństwa, wydłużając tym samym dzielący obie grupy dystans. Po drugie osoby niepełnosprawne, wbrew tendencjom rynku pracy, częściej niż sprawni wybierają zasadnicze szkoły zawodowe, a ich kształcenie zawodowe jest głównie podporządkowane nie potrzebom rynku pracy lecz zasobom instytucji kształcących. Dlatego też

10 A. Krause, Człowiek niepetnosprawny wobec przeobrażeń społecznych, Wydawnictwo Impuls, Kraków 2004, s. 39.

11 B. Fatyga, B. Balcerzak-Paradowska, Biała księga młodzieży polskiej. Diagnoza sytuacji młodych Polaków jako podstawa strategii państwa dla młodzieży, Wydawnictwo MENiS, Warszawa 2004, s. 184.

12 Badania wptywu kierunku i poziomu wykształcenia na aktywność zawodowa osób niepetnosprawnych, Pentor Research International, s. 44 http://www.pfron.org.pl/ ftp/dokumenty/Badania_i_analizy/Raport_CZESC_1z6_final.pdf [dostęp: 25.05.2016].

13 Raporty GUS poświęcone edukacji w Polsce, http://stat.gov.pl/obszarytematyczne/edukacja/edukacja/ [dostęp; 20.05.2016].

14 Badania wptywu kierunku i poziomu wyksztatcenia na aktywność zawodowa osób niepetnosprawnych, Pentor Research International, s. 47 http://www.pfron.org.pl/ ftp/dokumenty/Badania_i_analizy/Raport_CZESC_1z6_final.pdf [dostęp: 25.05.2016]. 
największe szanse na znalezienie zatrudnienia mają niepełnosprawni (podobnie jak sprawni) z wykształceniem wyższym. Jak wykazały badania dla 67,6\% niepełnosprawnych respondentów studia wyższe oznaczają szansę na znalezienie pracy. Z kolei 16,9\% osób deklarowało pragnienie zdobycia wymarzonego zawodu, ale również badani wskazywali wybór studiów jako alternatywy dla braku perspektyw życiowych (7\%), możliwość kontaktu z rówieśnikami $(4,2 \%)$, chęć pogłębiania swojej wiedzy $(2,8 \%)$, natomiast $1,4 \%$ badanych wskazywało na namowę rodziców i znajomych do podjęcia studiów wyższych ${ }^{15}$.

Studenci z niepełnosprawnościami są nadal niewielką grupą na uczelniach wyższych. Z Raportu Marcina Garbata i Marii A. Paszkowicz „Studenci z niepełnosprawnościami w polskich szkołach wyższych" wynika, iż w 2012 r. studiowało na polskich uczelniach 30 tys. osób z różnego typu niepełnosprawnościami ${ }^{16}$. Wśród niepełnosprawnych studentów najliczniejszą grupą studiującą (ponad $50 \%$ ) są osoby z chorobami przewlekłymi, następnie z niepełnosprawnością motoryczną $(28,6 \%)$, są też osoby niewidome i słabowidzące (2733), dalej osoby niesłyszące i słabosłyszące (20 470). W statystykach uczelni można też zaobserwować rosnącą liczbę osób z chorobami psychicznymi. Schizofrenia, nerwica natręctw, anoreksja, bulimia, stany lękowe - coraz więcej studentów boryka się z tymi problemami. Niepełnosprawni najchętniej wybierają państwowe uczelnie wyższe i są to głównie uniwersytety, następnie wyższe szkoły zawodowe, szkoły ekonomiczne, techniczne i pedagogiczne. Najmniej popularne wśród osób z niepełnosprawnościami są uczelnie obrony narodowej i resortu spraw wewnętrznych, teologiczne, wychowania fizycznego oraz artystyczne ${ }^{17}$.

15 G. Miłkowska, Aspiracje życiowe studentów niepetnosprawnych, [w:] Osoba niepetnosprawna w społeczności akademickiej, red. H. Ochonczenko, G. Miłkowska, Wydawnictwo Impuls, Kraków 2005, s. 69.

${ }_{16}$ M. Garbat, M.A. Paszkowicz, Studenci z niepetnosprawnościami w polskich szkołach wyższych, STUDIA OECONOMICA POSNANIENSIA 2015, 3, 10, s. 116.

17 Ibidem, s. 117-128. 
Pytanie o studia wyższe osób niepełnosprawnych to także pytanie o realne możliwości uczelni $\mathrm{w}$ stworzeniu optymalnych warunków do nauki tej grupie osób. Należy bowiem pamiętać, iż niepełnosprawni kandydaci na studentów posiadają zróżnicowane stopnie i rodzaje niepełnosprawności, a co się z tym wiąże - wymagają zindywidualizowanej pomocy $\mathrm{w}$ zakresie organizacji specjalistycznego sprzętu, zabezpieczenia socjalnego czy choćby dowozu na zajęcia. Warto zwrócić uwagę, że naukę na studiach wyższych podejmują najczęściej najzdolniejsze osoby niepełnosprawne ${ }^{18}$. W tym miejscu należy wskazać na trudności pojawiające się najczęściej na drodze do pełnego otwarcia uczelni wyższych dla osób z niepełnosprawnościami. Pierwszą z nich jest oczywiście kwestia finansowa, gdyż studiowanie osób niepełnosprawnych wymaga od uczelni ponoszenia znacznie większych kosztów aniżeli w stosunku do osób sprawnych (np. dostosowanie budynków czy wyposażenia specjalistyczny sprzęt). Kolejnymi istotnymi barierami są bariery o wiele trudniejsze do pokonania, a mianowicie problemy psychologiczne, bazujące na wieloletnich uprzedzeniach, stereotypach i lękach skierowanych wobec osób niepełnosprawnych. Jak uważa Agnieszka Nowicka, następstwa i stereotypy w postrzeganiu osób $\mathrm{z}$ niepełnosprawnościami są $\mathrm{w}$ uczelniach widoczne $\mathrm{w}$ postawach nauczycieli akademickich, oraz studentów. Wpływ na takie postrzeganie niepełnosprawnych studentów mają nabyte uprzedzenia przypisujące osobom niepełnosprawnym pewne zgeneralizowane ograniczenia, które wpływają na ich szanse życiowe ${ }^{19}$. Warto podkreślić, że dla studentów z niepełnosprawnościami fakt akceptacji ich osoby w środowisku akademickim może się okazać o wiele ważniejszy aniżeli optymalizacja warunków technicz-

${ }^{18}$ A. Witek, Z. Kazanowski, Możliwości funkcjonowania osób niepetnosprawnych w roli studentów uczelni wyższych. Komunikat $z$ badań, [w:] Jakość życia a niepetnosprawność. Konteksty psychopedagogiczne, red. Z. Palak, A. Lewicka, A. Bujnowska, Wydawnictwo UMCS, Lublin 2006.

${ }^{19}$ A. Nowicka, Przestrzeganie przez niepetnosprawnych studentów postaw wobec ich osoby koleżanek $i$ kolegów z roku, [w:] Osoba niepetnosprawna w społeczności akademickiej, red. H. Ochonczenko, G. Miłkowska, Oficyna Wydawnicza „Impuls”, Kraków 2005. 
nych ${ }^{20}$. Niezwykle istotne zatem staje się zwiększanie świadomości społeczności akademickiej na temat niepełnej sprawności, problemów z nią związanych i strategii radzenia sobie z nimi.

\section{Aktywność zawodowa osób z niepełnosprawnościami}

Pomimo iż osoby z niepełnosprawnościami stanowią kilkanaście procent polskiego społeczeństwa, to jednak ich udział w rynku pracy jest nadal niewielki - w 2014 r. jedynie 27,4\% osób niepełnosprawnych w wieku produkcyjnym było aktywnych zawodowo ${ }^{21}$. W literaturze przedmiotu zawsze podkreśla się doniosłe znaczenie pracy w życiu osób z niepełnosprawnościami. Oprócz potrzeb stricte ekonomicznych, praca zawodowa zaspokaja liczne potrzeby pozaekonomiczne - szczególnie w wymiarze społecznym i psychicznym: potrzebę kontaktu z innymi ludźmi, samorealizacji, rozwoju i potwierdzenia własnych możliwości, daje poczucie sprawstwa, bycia użytecznym dla swojej rodziny i społeczeństwa. Wykonywanie pracy zarobkowej zwiększa aspiracje życiowe, powoduje wzrost jakości życia oraz przeciwdziała izolacji i wykluczeniu społecznemu. Sam fakt bycia osobą zatrudnioną, pracującą i zarabiającą odgrywa w życiu osoby z niepełnosprawnościami bardzo ważną rolę w procesie ich integracji ze społeczeństwem oraz satysfakcjonującej realizacji siebie. Pozwala ona na osiągnięcie zwiększonej niezależności ekonomicznej, wzbogaca kontakty i formy uczestnictwa społecznego, pomaga w osiągnięciu poczucia przydatności społecznej. Może zatem pełnić zarówno funkcję ekonomiczną, jak i samorealizacyjną oraz zapobiegać procesowi izolacji społecznej22.

${ }^{20}$ W. Dykcik, Aktywność lokalnych środowisk osób niepetnosprawnych szansą na integrację i życiowe ukierunkowanie, [w:] Pedagogika specjalna, red. W. Dykcik, Wydawnictwo Naukowe UAM, Poznań 2001, s. 272.

${ }^{21}$ Współczynnik aktywności zawodowej osób sprawnych wyniósł 72,1\% - dane BAEL, źródło: www.niepelnosprawni.gov.pl/ [dostęp: 20.05.2016].

22 M. Struck-Peregończyk, Czynniki ksztattujące aktywność zawodowa młodych osób niepetnosprawnych na przykładzie województwa podkarpackiego, [w:] Polscy NiePetnos- 
Istnieje jednak wiele czynników, które mają wpływ na podjęcie aktywności zawodowej przez osoby niepełnosprawne. Część barier wynika z warunków otoczenia - trudna sytuacja na rynku pracy, skomplikowane zapisy regulacji prawnych, brak stabilności prawa, brak ofert pracy dla osób niepełnosprawnych, brak pomocy w poszukiwaniu pracy ze strony odpowiednich instytucji, bariery transportowe ${ }^{23}$. Ważnym czynnikiem są też niechętne postawy pracodawców i bariery wynikające $\mathrm{z}$ warunków środowiska pracy (konieczność przystosowania stanowisk pracy, występowanie barier funkcjonalnych, uprzedzenia współpracowników) ${ }^{24}$. Istotne są również czynniki wynikające z samej niepełnosprawności - jej rodzaj, stopień i moment nabycia, a także bariery wynikające z postaw i cech samych osób niepełnosprawnych - brak motywacji, niski poziom wykształcenia i przygotowania zawodowego, brak wiedzy o sposobach poszukiwania pracy i działalności instytucji wsparcia, niższa mobilność 25 . To, w jaki sposób osoba z ograniczeniami sprawności odnajdzie się na rynku pracy, zależy od kilku istotnych i powiązanych ze sobą czynników, takich jak m.in.: przyczyna i rodzaj niepełnosprawności, stopień w jakim utrudnia ona osobie funkcjonowanie (nie tylko w sferze zawodowej, ale i życiu codziennym), wykształcenie (rozumiane tu jako posiadaną wiedzę teoretyczną i umiejętności praktyczne) system wsparcia czy sposób, w jaki osoba niepełnosprawna myśli o pracy. Tak więc doradztwo zawodowe, znalezienie odpowiedniego zatrudnienia dla osoby niepełnosprawnej, jest zadaniem wielowymiarowym, uwzględnia-

Prawni pomiędzy deklaracjami, (red.) B. Gąciarz, S. Rudnicki, D. Żuchowskiej-Skiby 2015, s. 43-62.

${ }^{23}$ E. Giermanowska, Postrzeganie niepetnosprawnych pracowników i uwarunkowania ich zatrudnienia a zarzadzanie personelem w organizacjach, [w:] B. Gąciarz i E. Giermanowska (red.). Zatrudniając niepetnosprawnych. Wiedza, opinie i doświadczenia pracodawców, Instytut Spraw Publicznych, Warszawa 2009, s. 65-70.

${ }^{24}$ E. Rutkowska, J. Rakowska, Bariery w aktywizacji zawodowej osób z niepetnosprawnościa, [w:] M. Piasecki i J. Śliwak (red.). Wybrane zagadnienia z aktywizacji zawodowej osób niepełnosprawnych, Norbertinum, Lublin 2008, s. 30-35.

25 A.I. Brzezińska, K. Piotrowski, op. cit., s. 26. 
jącym nie tylko zachowane przez nią możliwości i zainteresowania, ale także szereg czynników psychologicznych i motywacyjnych ${ }^{26}$.

Współczesna sytuacja gospodarcza, w warunkach silnej konkurencyjności, rotacyjności i niepewności, zamiast motywować niepełnosprawnych do podejmowania zatrudnienia na otwartym rynku pracy, pogłębia bierność i wyizolowanie społeczne. Dla blisko połowy $(43,5 \%)$ osób niepełnosprawnych w Polsce głównym źródłem utrzymania są źródła niezarobkowe - renta inwalidzka, renta socjalna, renta rodzinna, zasiłek dla bezrobotnych, świadczenia z pomocy społecznej. Dość duża grupa $(30,5 \%)$ młodych osób niepełnosprawnych była na utrzymaniu innych osób, jedynie dla 22,3\% głównym źródłem utrzymania były dochody z pracy ${ }^{27}$. System rentowy jest mało elastyczny i nie uwzględnia specyficznych potrzeb osób niepełnosprawnych ze względu np. na koszty, jakie dana osoba niepełnosprawna musi ponieść, aby zniwelować skutki swojej choroby i móc podjąć pracę - czym innym jest przecież konieczność zakupu kuli, a czym innym zakup aktywnego wózka w celu dotarcia do miejsca pracy. Zamiast przywilejów niepełnosprawni woleliby dostać lepsze narzędzia i środki wyrównania szans, pozwalające uzyskać "protezy” niwelujące skutki ich niepełnosprawności - są gotowi radzić sobie samodzielnie na rynku pracy jedynie $\mathrm{z}$ minimalnym wsparciem ${ }^{28}$. Według ostatniego Europejskiego Ankietowego Badania Zdrowia szacuje się, że prawne orzeczenie o niepełnosprawności lub równoważne posiadało ponad 3,8 mln mieszkańców Polski. Szacując ogólną liczbę niepełnosprawnych w Polsce, należy również ująć zbiorowość osób, które co prawda orzeczenia o niepełnosprawności nie posiadają, lecz deklarują, że mają ograniczenia w wykonywaniu zwykłych czynności. W zależności od przyjętego kryterium niepełnosprawności, a ściślej mówiąc - poziomu ograni-

${ }^{26}$ M. Struck-Peregończyk, op. cit., s. 43-62.

27 Ibidem, s. 45-47.

${ }^{28} \mathrm{~J}$. Kalita, Sytuacja osób niepetnosprawnych na rynku pracy oraz rola organizacji pozarządowych świadczacych ustugi dla tej grupy beneficjentów, Bezrobocie. Co robić?, Wydawnictwo FISE, Warszawa 2006, s. 5. 
czeń populacja osób niepełnosprawnych w Polsce może liczyć nawet 4,9 mln osób²9.

Nadal aktualne, pomimo wielu programów promujących zatrudnienie osób niepełnosprawnych, są bariery społeczne i mentalne. Pracodawcy nieznający specyfiki niepełnosprawności mogą wykazywać negatywny stosunek do zatrudniania osób z niepełnosprawnościami w swoich firmach, mogą też posługiwać się nieprawdziwymi, krzywdzącymi dla niepełnosprawnych opiniami na temat ich pracy. Ankietowani pracodawcy wymieniają, iż istnieje ograniczony repertuar zawodów, które może wykonywać osoba $\mathrm{z}$ niepełnosprawnością. Innym problemem według pracodawców mogą okazać się znaczne koszty przystosowania stanowiska pracy do potrzeb osób z niepełnosprawnościami czy konieczność zapewnienia ciągłej opieki i ochrony w trakcie pracy, gdyż osoby niepełnosprawne mogą stanowić zagrożenie dla siebie i innych osób. Kolejnymi problemami jest według pracodawców spadek wydajności i jakości pracy (co przy dobrym przeszkoleniu okazuje się mitem) i trudności w integracji zespołu pracowniczego ${ }^{30}$. Wszystkie powyższe obawy pracodawców można rozwiać przez odpowiednio przeprowadzony system szkoleń i rozmów doradczych (z zakresu przybliżenia specyfiki niepełnosprawności, radzenia sobie w sytuacjach trudnych czy możliwości wsparcia pracodawców zatrudniających niepełnosprawnych w ramach PFRON) z pracodawcami, osobami niepełnosprawnymi i zespołem pracowniczym. Problemy wspólnej pracy stają się potencjalnie konfliktotwórcze, gdy wykraczają poza ogólnie ustalone deklaracje. Jak dowodzą badania A. Ostrowskiej, można zauważyć rysujące się poczucie konkurencyjności w odniesieniu do zatrudniania osób niepełnosprawnych

${ }^{29}$ M. Piekarzewska, A. Zajenkowska-Kozłowska Zdrowie i zachowanie zdrowotne mieszkańców Polski w świetle Europejskiego Ankietowego Badania Zdrowia (EHIS) 2014, Wydział Statystyki Zdrowia Departament Badań Społecznych i Warunków Życia, Warszawa 2015.

${ }^{30} \mathrm{H}$. Ochonczenko, Sytuacja na rynku pracy osób niepetnosprawnych $w$ dobie zmian społecznych $i$ gospodarczych w Polsce, [w:] Człowiek niepetnosprawny w różnych fazach życia, red. J. Bąbka, Wydawnictwo Akademickie Żak, Warszawa 2004. 
i w konsekwencji do osiągania przez nich pewnych społecznie pożądanych dóbr. Badania wskazują, ze fakt posiadania przez osoby niepełnosprawne stałych, comiesięcznych świadczeń (renty) przesądza, iż $40 \%$ badanych wskazało, że nie powinni oni w ogóle zajmować miejsc na rynku pracy, podczas gdy brakuje pracy dla osób sprawnych. Ponadto połowa badanych stwierdziła również, że osoby niepełnosprawne posiadające takie same kwalifikacje i doświadczenia zawodowe jak osoby sprawne, mają mniejsze od nich szanse na awans społeczny ${ }^{31}$.

Według Stanisława Kowalika najczęstszymi problemami osób $\mathrm{z}$ niepełnosprawnościami, jakie wskazują pracownicy tego typu instytucji, są: (1) konflikt związany z oceną (akceptacją) posiadanej niepełnosprawności, przechodzący od skrajnie negatywnych do pozytywnych odczuć wobec własnej niepełnosprawności, (2) stosowanie kompensacyjnych mechanizmów obronnych w odpowiedzi na traumatyczne przeżycie, (3) niepewność, brak wiary we własne możliwości, (4) brak motywacji do działania skutkujący niepodejmowaniem aktywnych działań na rynku pracy (nawet w wyuczonym zawodzie), (5) brak właściwego systemu segmentacji czasu życia, co utrudnia planowanie i celowe działanie (niepełnosprawność jako przeszkoda w realizacji szans życiowych) ${ }^{32}$. Innym ważnym czynnikiem, o którym była mowa wcześniej, są według Kowalika wszelkie zachowania o charakterze dyskryminującym wobec osób z niepełnosprawnościami. W efekcie zachowania te doprowadzić mogą do marginalizacji społecznej czy obawy przed negatywnymi postawami pracodawców lub innych pracowników. Autor ten wyróżnia kilka rodzajów dyskryminacji tworzących swoiste kontinuum negatywnych postaw wobec niepełnosprawnych: dystansowanie się (unikanie wchodzenia $\mathrm{w}$ bliższe i nieformalne relacje), dewaluowanie (upowszechniania własnych przekonań o negatyw-

31 Raport Integracji Niepetnosprawni - Normalna sprawa, Warszawa 2002, http://www.niepelnosprawni.pl/ledge/x/1402 [dostęp: 20.05.2016].

32 S. Kowalik, Psychologia rehabilitacji, Wydawnictwa Akademickie i Profesjonalne, Warszawa 2007. 
nych właściwościach osób niepełnosprawnych lub ich grup), delegitymizację (prawne utrwalanie negatywnego stosunku pełnosprawnych do niepełnosprawnych), segregację (fizyczne izolowanie osób niepełnosprawnych od środowiska społecznego) oraz eksterminację (biologiczne wyniszczanie ludzi przynależnych do określonej kategorii społecznej) $)^{33}$.

\section{Doradztwo zawodowe osób z niepełnosprawnościami}

Aby umożliwić osobom z niepełnosprawnościami funkcjonowanie na rynku pracy, niewątpliwie należy poznać specyfikę trudności doświadczanych przez klientów doradców zawodowych. Poradnictwo zawodowe stanowi pierwszy etap rehabilitacji zawodowej osób z ograniczeniami sprawności. Poradnictwo to, jak zauważa Tadeusz Majewski, to proces polegający na udzielaniu pomocy osobom $\mathrm{z}$ ograniczoną zdolnością do pracy $\mathrm{w}$ podjęciu decyzji zawodowej, czyli wyborze odpowiedniej kariery zawodowej. Autor ten wyróżnia dwie kategorie odbiorców poradnictwa zawodowego. Pierwszą stanowi młodzież z niepełnosprawnościami, stająca przed wyborem dalszej ścieżki kształcenia i wymagająca wsparcia w wyborze odpowiedniego zawodu. Drugą kategorią są dorośli niepełnosprawni, którzy wymagają rehabilitacji zawodowej, nie mają przygotowania do pracy i dotychczas nie wykazywali oni aktywności zawodowej. Do tej grupy zaliczyć można również osoby dorosłe, które utraciły sprawność w czasie wykonywania pracy i w następstwie tego wymagają przekwalifikowania zawodowego. Według Tadeusza Majewskiego rehabilitacja zawodowa to jeden z elementów rehabilitacji kompleksowej, której działanie skupia się na pomocy osobom niepełnosprawnym w uzyskaniu i utrzymaniu zatrudnienia. Działania, które składają się na realizację tych zadań, to poradnictwo zawodowe, przygotowanie do pracy w tym szkolenia zawodowe, pośrednictwo pracy i zatrudnienie. To także, co

33 Ibidem. 
szczególnie podkreśla ten autor, adaptacja w środowisku pracy ${ }^{34}$. Warto na koniec podkreślić, że znalezienie pracy dla pracownika z niepełnosprawnościami wymaga od doradcy wysiłku nie tylko odszukania odpowiedniej oferty czy zdiagnozowania potrzeb zawodowych klienta, ale głównie poznania specyfiki niepełnosprawności i co najważniejsze - empatii w relacji doradczej. Warto także pamiętać, że samo przystosowanie miejsca pracy, szczególnie na otwartym rynku pracy wiąże się także z przygotowaniem innych pracowników. Ważne, by w miejscu pracy osoba $\mathrm{z}$ niepełnosprawnością czuła się akceptowana i bezpieczna.

W artykule zostały przeanalizowane wybrane trudności życiowe z obszaru edukacji i pracy, których mogą doświadczać młode osoby z niepełnosprawnościami. Wkraczanie w dorosłość wymaga $\mathrm{z}$ jednej strony uporu $\mathrm{w}$ realizacji własnych planów i zamierzeń, z drugiej zaś dostosowania się do ograniczeń i możliwości realiów życiowych, wymagań życia codziennego oraz oczekiwań osób wspierających. Młode osoby z niepełnosprawnościami mogą doświadczać wielu ograniczeń biologicznych, materialnych, psychicznych i społecznych w konkretyzacji i realizacji własnej wizji swojego dorosłego życia, które utrudniają proces poszukiwania swojego miejsca w świecie. Często wybory życiowe, zawodowe, edukacyjne i inne, są podporządkowane sprawom zdrowotnym lub preferencjom rodziny. Warto wspierać młode osoby z niepełnosprawnościami, aby pomimo przeszkód, miały odwagę realizować siebie w swoim dorosłym życiu.

\section{Bibliografia}

Badania Aktywności Ekonomicznej Ludności (BAEL) GUS, 2016, http://stat.gov.pl/ informacja-o-badaniach-ankietowych/badanie-aktywnosci-ekonomicznej-ludnoscibael/ [dostęp: 20.05.2016].

34 T. Majewski, Jak zatrudniać osoby niepetnosprawne: poradnik dla pracodawców, Krajowa Izba Gospodarczo-Rehabilitacyjna, Warszawa 2007. 
Badania wptywu kierunku i poziomu wykształcenia na aktywność zawodowa osób niepetnosprawnych, Pentor Research International, http://www.pfron.org.pl/ftp/doku menty/Badania_i_analizy/Raport_CZESC_1z6_final.pdf [dostęp: 20.05.2016].

Bee H., Psychologia rozwoju człowieka, Zysk i Spółka, Poznań 2008.

Brzezińska A.I., Piotrowski K., Aktywność zawodowa osób z ograniczeniem sprawności wyznaczniki społeczno-demograficzne i osobowościowe, Warszawa: Wydawnictwo SWPS „Academica” 2008.

Brzezińska A., Kaczan R., Piotrowski K., Rękosiewicz M., Odroczona dorostość: fakt czy artefakt?, „Nauka” 2011, 4.

Brzezińska A., Psychologiczne portrety człowieka, GWP, Gdańsk 2015.

Dykcik W., Aktywność lokalnych środowisk osób niepetnosprawnych szansa na integracje i życiowe ukierunkowanie, [w:] Pedagogika specjalna, red. W. Dykcik, Wydawnictwo Naukowe UAM, Poznań 2001.

Edukacja w zarysie, Raport, OECD 2015, http://www.oecd-ilibrary.org/education/ education-at-a-glance-2015_eag-2015-en [dostęp: 20.05.2016].

Fatyga B., Balcerzak-Paradowska B., Biała księga młodzieży polskiej. Diagnoza sytuacji młodych Polaków jako podstawa strategii państwa dla młodzieży, Wydawnictwo MENiS, Warszawa 2004.

Garbat M., Paszkowicz M.A., Studenci z niepetnosprawnościami w polskich szkołach wyższych, STUDIA OECONOMICA POSNANIENSIA 2015, 3, 10,

Harwas-Napierała B., Dorosłość jako spetnienie. Drogi i zagrożenia rozwoju człowieka w okresie dorostości, Libron, Kraków 2012.

Jarmużek J., Rozwojowe implikacje dorostości, [w:] Edukacja. Uniwersytet. Oświata dorostych, red. W. Ambrozik, Wydawnictwo Naukowe UAM, Poznań 2014.

Kalita J., Sytuacja osób niepetnosprawnych na rynku pracy oraz rola organizacji pozarzadowych świadczacych ustugi dla tej grupy beneficjentów, Bezrobocie. Co robić?, Wydawnictwo FISE, Warszawa 2006.

Kowalik S., Psychologia rehabilitacji, Wydawnictwa Akademickie i Profesjonalne, Warszawa 2007.

Krause A., Człowiek niepetnosprawny wobec przeobrażeń społecznych, Oficyna Wydawnicza „Impuls”, Kraków 2004.

Majewski T., Jak zatrudniać osoby niepetnosprawne? poradnik dla pracodawców, Krajowa Izba Gospodarczo-Rehabilitacyjna, Warszawa 2007.

Miłkowska G., Aspiracje życiowe studentów niepetnosprawnych, [w:] Osoba niepetnosprawna w społeczności akademickiej, red. H. Ochonczenko, G. Miłkowska, Oficyna Wydawnicza „Impuls”, Kraków 2005.

Nowicka A., Przestrzeganie przez niepetnosprawnych studentów postaw wobec ich osoby koleżanek i kolegów z roku, [w:] Osoba niepetnosprawna w społeczności akademickiej, red. H. Ochonczenko, G. Miłkowska, Oficyna Wydawnicza „Impuls”, Kraków 2005.

Ochonczenko H., Sytuacja na rynku pracy osób niepetnosprawnych $w$ dobie zmian społecznych i gospodarczych w Polsce, [w:] Człowiek niepetnosprawny w różnych fazach $\dot{z}$ ycia, red. J. Bąbka, Wydawnictwo Akademickie Żak, Warszawa 2004. 
Piekarzewska M., Zajenkowska-Kozłowska A. Zdrowie i zachowanie zdrowotne mieszkańców Polski w świetle Europejskiego Ankietowego Badania Zdrowia (EHIS) 2014 r., GUS, 2015, Wydział Statystyki Zdrowia Departament Badań Społecznych i Warunków Życia.

Raport Integracji Niepetnosprawni - Normalna sprawa, Warszawa 2002, http:/ / www. niepelnosprawni.pl/ledge/x/1402 [dostęp: 20.05.2016].

Raporty GUS poświęcone edukacji w Polsce, http://stat.gov.pl/obszary-tematycz ne/edukacja/edukacja/ [dostęp: 20.05.2016].

Raszeja-Ossowska I., Młodzi - niepetnosprawni Sytuacja społeczna i zawodowa, Fundacja Aktywizacja, Warszawa 2013.

Rutkowska E., Rakowska J., Bariery w aktywizacji zawodowej osób z niepetnosprawnościa, W: M. Piasecki i J. Śliwak (red.). Wybrane zagadnienia z aktywizacji zawodowej osób niepetnosprawnych, Norbertinum, Lublin 2008.

Struck-Peregończyk M., Czynniki kształtujące aktywność zawodowa młodych osób niepetnosprawnych na przykładzie województwa podkarpackiego, [w:] Polscy Niepetnosprawni pomiędzy deklaracjami, red. B. Gąciarz, S. Rudnicki, D. Żuchowskiej-Skiby, Wydawnictwa AGH, Kraków 2015.

Witek A., Kazanowski Z., Możliwości funkcjonowania osób niepełnosprawnych w roli studentów uczelni wyższych. Komunikat z badań, [w:] Jakość życia a niepetnosprawność. Konteksty psychopedagogiczne, red. Z. Palak, A. Lewicka, A. Bujnowska, Wydawnictwo UMCS, Lublin 2006. 